\title{
Study of the Rainfall Infiltration Effect and Soil Strength Variation on Unsaturated Laterite Terraces
}

\author{
Shao-Hung Chung ${ }^{1}$ \\ ${ }^{1}$ Department of Civil Engineering and Environmental Informatics, Minghsin University of Science and Technology \\ No.1, Xinxing Rd., Xinfeng Hsinchu, 30401, Taiwan (R.O.C.) \\ shj@must.edu.tw
}

\begin{abstract}
The lateritic terraces of northern Taiwan have unsaturated soil due to their higher elevation and deeper groundwater level. Under the effects of rainfall infiltration and surface evaporation, the topsoil often changes in humidity; thus, the soil strength also changes. As there are a large number of structures in these terraces, it is necessary to further understand the influence of rainwater infiltration in order to design a safe and economical foundation structure. In this paper, tensiometers were installed in-situ to observe changes in soil matric suction. An undisturbed soil column was taken and drying and wetting tests were conducted to understand the depth of water infiltration. Meanwhile, a direct shear test was performed using specimens with different water contents taken from the soil column. The corresponding soil matric suction was derived from the relationship of the soil water content and tensiometer readings of the tests. The results showed that, during rainwater infiltration, the soil near the surface reacted immediately. The influence of the rainwater infiltration reached about $120 \mathrm{~cm}$ below the surface. The soil shear strength decreased with the increasing soil moisture content. In other words, rainfall would reduce the soil matric suction and the shear strength of the soil would decrease.
\end{abstract}

Keywords: Matric Suction, Rainfall Infiltration, Soil Column, Direct Shear Test.

\section{Introduction}

Regions above the groundwater table often consist of unsaturated soil due to capillary phenomena, rainfall infiltration, and ground surface evaporation. It has been well recognized that negative pore-water pressure (matric suction) plays a crucial role in the stability of unsaturated soil slopes [1]. Matric suction $\left(\mathrm{u}_{\mathrm{a}}-\mathrm{u}_{\mathrm{w}}\right)$ influences the shear strength of unsaturated soil; when the soil moisture content decreases, the matric suction will be higher, which is revealed in a higher shear strength. As the rainwater infiltrates the soil, the matric suction of the soil and the soil strength decreases. Consequently, shallow geotechnical structures and slopes may be prone to damage. The affected zone of rainwater infiltration can be determined by measuring the matric suction of the topsoil.

The lateritic terraces in northern Taiwan are examples of the above-mentioned stratum and have been developed extensively. There are miscellaneous light-weight structures in the area, such as shallow foundations, pavement, mini piles, shallow-depth buried pipes, and retaining walls, etc. that have been constructed and buried in unsaturated soil. Variations in the water content on the top layer of soil will affect these structures' behaviours. Therefore, the depth of rainfall infiltration is an important factor when designing structures that are founded in and on unsaturated regions.

In this paper, in-situ infiltration observations were undertaken on the Hsinchu plateau in northern Taiwan and an undisturbed laterite column specimen was retrieved for laboratory infiltration testing. In order to grasp the effects of rainfall infiltration and evaporation on matric suction, tensiometers were installed on the field and in soil column at different depths, and long-term matric suction monitoring data were presented. In addition, the traditional direct shear test was conduct using specimens with different water contents that were taken from the soil column. Finally, the effects of infiltration on matric suction and soil strength were discussed.

\section{Experimental method}

\subsection{Experimental soil}

Lateritic soils are widely distributed in arid and semi-arid climatic regions in the world. In Taiwan, lateritic soil covers almost $2 / 3$ of all of hillsides and terraces [2] and is located in a hot and rainy subtropical region with an average annual rainfall of about $2500 \mathrm{~mm}$. About $80 \%$ of the annual rainfall occurs between May and September. In this region, lateritic 
soils continuously undergo wetting and drying cycles due to the changeable seasons. The lateritic soil has a high percentage of montmorillonite and illite, resulting in a low strength and high swelling potential [3]. The field test site was located in northern Taiwan and the stratum was composed of lateritic soil. The soil tested in this study for laboratory infiltration was taken from 0.6-1.3 m below the surface. During sampling, the field moist density and dry unit weight of the soil was determined using the sand cone method (ASTM D1556-64). The particle-size distribution showed that the soil was comprised of $18 \%$ sand, $52 \%$ silt, and $30 \%$ clay. The basic physical properties of this soil are depicted in Table 1. The soil was classified as low plasticity clay according to the Unified Soil Classification System.

Table 1. Basic soil properties.

\begin{tabular}{|l|c|}
\hline \multicolumn{1}{|c|}{ Soil properties } & Value \\
\hline Mean particle size $\mathrm{d}_{50}(\mathrm{~mm})$ & 0.02 \\
\hline Liquid limit LL $(\%)$ & 38 \\
\hline Plastic limit PL $(\%)$ & 22 \\
\hline Clay fraction $($ grain size $<2 \mu \mathrm{m}) \mathrm{CF}(\%)$ & 30.0 \\
\hline Specific gravity Gs & 2.67 \\
\hline Void ratio e & 0.61 \\
\hline Moist unit weight $\mathrm{r}_{\text {wet }}\left(\mathrm{kN} / \mathrm{m}^{3}\right)$ & 20.14 \\
\hline Dry unit weight $\mathrm{r}_{\mathrm{d}}\left(\mathrm{kN} / \mathrm{m}^{3}\right)$ & 16.64 \\
\hline
\end{tabular}

\subsection{Field infiltration monitoring}

Top-layer soils have reduced matric suction due to rainfall infiltration [4], which in turn reduces soil strength. The mechanism of rainfall infiltration is complex due to the high nonlinearity of soil water characteristics and soil permeability [5]. The affected zone of rainwater infiltration can be determined by measuring the matric suction of topsoil [6]. Numerous researchers have studied the effects of rainfall infiltration on slope stability [7] [8]. Tensiometers are commonly used to monitor matric suction in the field and can measure suctions up to $100 \mathrm{kPa}$ [9] [10] [11].

The surface of the test site was flat and covered with natural grass. The height of the vegetation ranged from 5 to $30 \mathrm{~cm}$ and the root depth observed on excavated surfaces ranged from 5 to $20 \mathrm{~cm}$. Measurements taken from a test pit showed that the groundwater level was about $4 \mathrm{~m}$ below the ground surface. Several Jet-filled type tensiometers were installed from 15 to $120 \mathrm{~cm}$ below the ground surface to observe soil matric suction changes due to rainfall infiltration. Meanwhile, a rain gauge was installed to automatically record the intensity and duration of rainfall.

Because a tensiometer is buried in the soil for a long time, its ceramic head is prone to blockage due to the breeding of bacteria in the soil and groundwater. It was thus necessary to clean the ceramic head and acrylic tube with a chlorine solution before using. After the tensiometers were installed, the installation holes were backfilled with moist soil and compacted to a density that matched the in-situ density to prevent rainwater from infiltrating down the surface of the tensiometer standpipes [12] [13]. It was important to ensure the ceramic cup had good contact with the surrounding soil for proper reaction responses. The observation work was performed from October 25 to December 19 of 2008 . The readings from the tensiometers were manually collected. At the end of the observation test, samples were collected for further laboratory soil moisture content test.

\subsection{Laboratory drying-wetting cycle test}

In the study of soil properties under controlled climatic conditions, soil column testing has been extensively discussed in the literature [14] [4] [15] [16]. According to Sentenac [17] the flow velocity around the column wall can be greater than that at the column center due to low compaction of the soil and the preferred pathway flow adjacent to the wall, particularly in small-diameter columns [16]. In this study, the undisturbed soil column specimen for the laboratory test was retrieved near the field infiltration test site. For the purpose of diminishing the flow velocity difference between the soil column's central area and the area around the column wall, the soil column diameter was set 
at $35 \mathrm{~cm}$ and the side surface of the soil column was carefully protected using cement mortar. The laboratory drying-wetting cycle test procedure was as described below [18].

1. The top $60 \mathrm{~cm}$ of weathered soil was excavated, carefully cut down, and then the soil column was trimmed to $35 \mathrm{~cm}$ in diameter and $70 \mathrm{~cm}$ in height.

2. A PVC pipe was inserted around the soil column as a protector. The PVC pipe must have a $40 \mathrm{~cm}$ inner diameter, a height of $100 \mathrm{~cm}$, and a thickness of $1.0 \mathrm{~cm}$.

3. Mix cement mortar and carefully pour it down to the gap between the soil column and the PVC pipe. Gently tap the PVC pipe with a plastic hammer to get rid of bubbles and fill the mortar tightly in the gap. This protective layer should be about $2.5 \mathrm{~cm}$ thick.

4. After five days of curing the soil column was cut off and carefully transported back to the laboratory.

5. Install tensiometers on the soil column at depths of 5, 10, 25, 40, 50 and $60 \mathrm{~cm}$. The tensiometers must undergo de-airing and saturation processes prior to installation.

Before installation, the tensiometer's plastic body tube was modified and bent to $80-90^{\circ}$ for a suitable horizontal install direction. Fig. 1 shows the layout of the soil column installed in the measuring system.

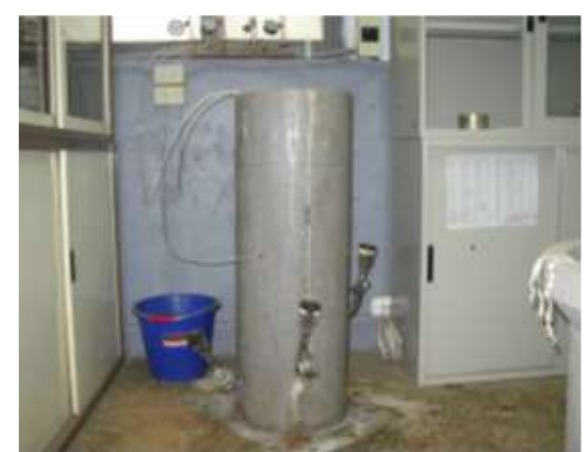

Fig. 1: Drying-wetting test system layout.

The tests were time-consuming because lateritic soil has low permeability, resulting in long test durations. The drying test was implemented first. The laboratory ventilation ran continuously to approach outside conditions. The ambient temperature was $25^{\circ} \mathrm{C}$ to $31^{\circ} \mathrm{C}$, and the soil column was not exposed to sunlight. After 50 days of air drying, the soil column was subjected to wetting from the top by maintaining $20 \mathrm{~cm}$ of artificially-ponded water every day. The infiltration test lasted for 60 days. When entering the winter, strong monsoons blow into Taiwan; the sunshine is no longer strong, and the weather becomes cold. Then, the drying test was cycled again for 40 days and the total duration of the cycling test was delayed 150 days. The matric suction value was manually collected.

\subsection{Traditional direct shear test}

At the end of the drying-wetting cycle test, soil column specimens were taken by a short thin-walled tube for the direct shear test and to measure the soil's water content.

Traditional consolidated undrained direct shear tests were conducted on the specimens. Three sets of specimens with different soil water contents were labeled as w19, w21 and w23, respectively. There were four specimens in each set with a spacemen diameter of $6.0 \mathrm{~cm}$ and a height of $2.0 \mathrm{~cm}$. The shear displacement rate of $0.514 \mathrm{~mm} / \mathrm{min}$ was adopted. The normal stress was set to 50,100, 150 and $200 \mathrm{kPa}$. Before shearing, the separation between upper and lower shear boxes was checked to ensure that there was no contact between the boxes. During the experiment, the direct shear boxes were wrapped with nylon stretch film to decrease changes in the moisture content of the soil. A computer system was used to record the test data. At the end of each test, the moisture content of the soil specimens was measured. 


\section{Results}

\subsection{Field infiltration test}

The in-situ observations began on October 25, 2009 and ended on December 19, 2009, lasting for 55 days. The test results, as shown in Fig. 2, revealed that the near-surface soil was affected by rainfall infiltration and the matric suction changed quickly. This observation may have been related to the preferential flow through fissures in the unsaturated However, the soil near the $120 \mathrm{~cm}$ depth had a slower response to rainfall infiltration. The daily rainfall on 12/05 was $\mathrm{mm}$, and the matric suction at $15 \mathrm{~cm}$ dropped quickly. Nevertheless, at 30 and $60 \mathrm{~cm}$, the matric suction was not reflected. When the accumulated rainfall exceeded $40 \mathrm{~mm}$, rainwater could infiltrate more than $120 \mathrm{~cm}$. The results indicated that the matric suction of the shallow soil decreased significantly, but the tensiometer readings at a depth of $120 \mathrm{~cm}$ showed a delay of one day.

Sunshine affected the field evaporation and was reflected in the matric suction readings. However, even in winter when the amount of sunshine is weak, under the action of a strong and cold monsoon, ground surface water will still evaporate and the matric suction will continue to increase. Fig. 2 also shows the surface soil under monsoon effects in which the matric suction increased to reach $100 \mathrm{kPa}$.

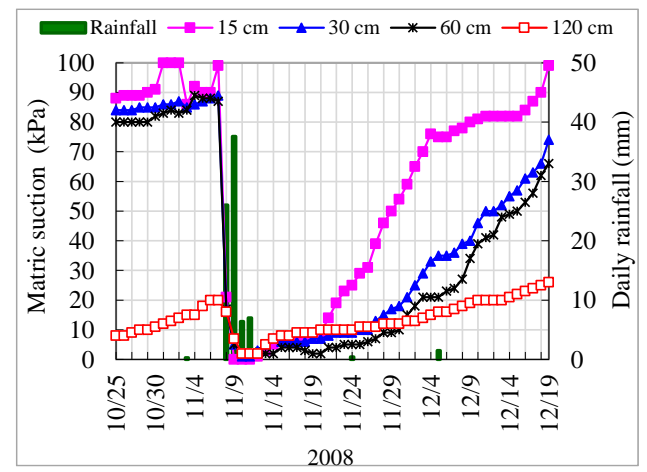

Fig. 2: Field test results.

\subsection{Laboratory drying-wetting cycle test}

The result of the 150-day cycle test on the soil column specimen is shown in Fig. 3. The result showed that:

1. Evaporation near the ground was quick. The tensiometers installed at depths of 5 and $10 \mathrm{~cm}$ responded immediately after the test began.

2. After 50 days of drying, a number of fine cracks were observed on the surface of the soil column, then the wetting test followed. With the help of these fissures, the infiltration effect was quickly observed at depths of less than $40 \mathrm{~cm}$.

3. At a depth of $60 \mathrm{~cm}$, during the initial and end cycles of the test, the matric suction value was $22 \mathrm{kPa}$. This means that depths below $60 \mathrm{~cm}$ were scarcely affected by the drying and wetting test. The cut off thickness of the surface layer was $60 \mathrm{~cm}$, therefore it could be presumed that the in-situ soil infiltration depth was close to $120 \mathrm{~cm}$. This result was close to the depth of the in-situ test, indicating that the laboratory test result was reliable.

4. The second drying curve was steeper than the first drying curve and was the result of wetting followed by drying exacerbating the fissures. It was speculated that after repeated wet and dry cycling, a fissure would have more downward development and the wetting-drying effect would occur faster and reach a deeper formation.

5. The matric suction on the soil saturation condition is $0 \mathrm{kPa}$, but the minimum reading at the $5 \mathrm{~cm}$ depth was $10 \mathrm{kPa}$, which was close to saturation condition. This result indicated that the soil column in the void ratio equaled 0.61 , and that the thickness of the infiltration effect on full saturation was less than $5 \mathrm{~cm}$. 


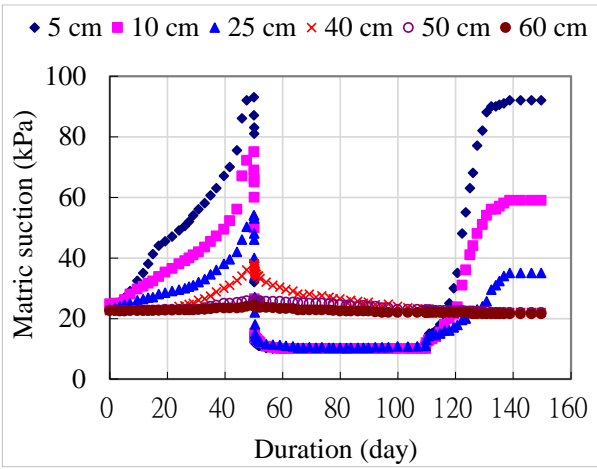

Fig. 3: Soil column laboratory test results.

Fig. 4 shows the relationship between the soil water content and soil matric suction values derived from the in-situ test and laboratory soil column test after the observations were finished. The results indicated that the increase in soil water content decreased the matric suction, and this trend was similar in both tests. The relationship between soil water content and soil matric suction value could be expressed as Eq. (1).

$$
\text { Matric suction } \mathrm{S}=101223 \mathrm{e}^{-0.365 w}
$$

where $\mathrm{S}$ is the soil matric suction, $\mathrm{w}$ is the soil water content, and e is the natural base of logarithms.

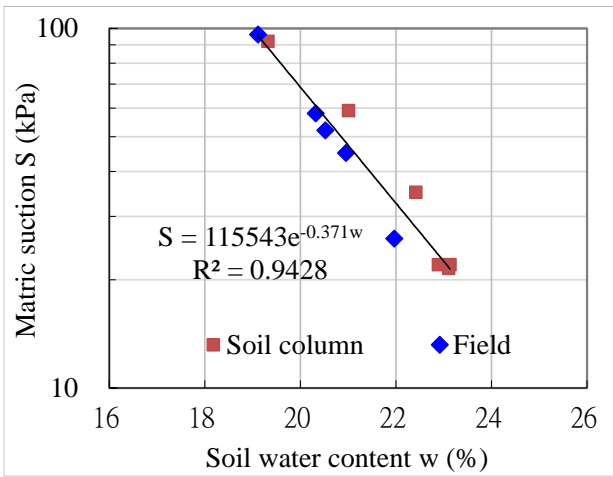

Fig. 4: Relationship between matric suction and water content.

\subsection{Direct shear test}

Undisturbed soil specimens were taken from the soil column were used for the direct shear test. The results of the shear stress and horizontal displacement relationship on unsaturated specimens w19, w21, and w23 for different normal stresses are shown in Fig. 5. The specimens with low moisture content and higher normal stress showed a peak followed by a decrease in shear stress before subsequently attaining a relatively constant value after $6 \mathrm{~mm}$ of horizontal displacement. However, when the moisture content was greater than $21 \%$, peaks in the stress curve were no longer observed. Instead, as the maximum shear stress was neared, constant strength was obtained. It could be said that as the soil water content increased, the shear failure behaviour of the specimen gradually turned from a brittle failure to a plastic failure model. 


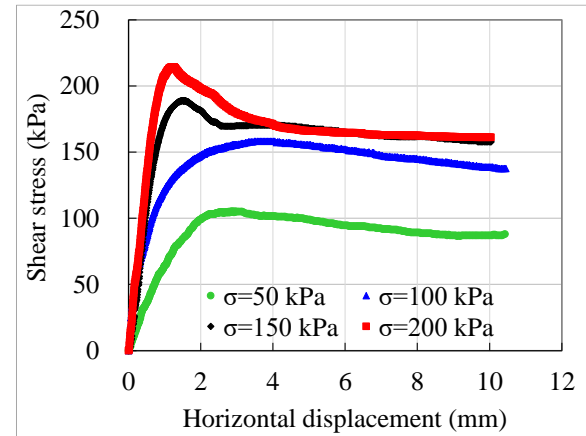

(a)

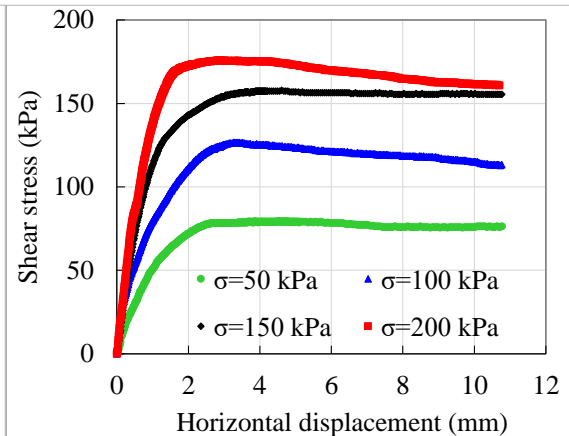

(b)

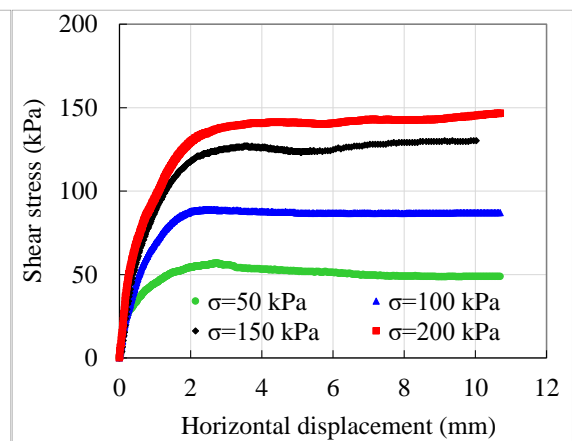

(c)

Fig. 5: Direct test result of (a)w19 (b)w21 and (c)w23.

The water content of the specimen after testing was converted to the corresponding soil matric suction according to Eq. (1). The calculated results are shown in Table 2 and the water content of the specimen before the direct shear test is shown in Table 2. The soil matric suction and failure shear stress are shown together in Fig. 6, which indicates that as the soil matric suction increased, the shear strength also increased. Meanwhile, as the normal stress increased, the shear stress increased as well. The effect of matric suction on shear strength could be described as having a non-linear relationship; the rate of increase seemed to gradually decrease with the increasing suction. These results indicated that the matric suction contributed to the shear strength of the unsaturated soil, which agreed with the results of other researchers [19] [14] [20 - 23].

Table 2. Result of soil matric suction via Eq. (1).

\begin{tabular}{|c|c|c|c|}
\hline Soil water content (before test), \% & 19.3 & 21.0 & 23.1 \\
\hline Soil water content (after test), \% & 19.2 & 20.7 & 22.9 \\
\hline Matric suction, kPa & 93.8 & 52.7 & 23.6 \\
\hline
\end{tabular}

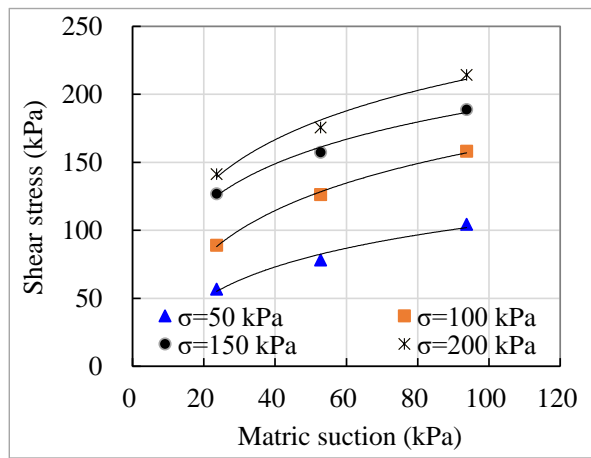

Fig. 6: Failure envelopes corresponding to different net normal stress.

According to the experimental results, the failure envelopes of the shear strength versus net normal stress under different soil water content values were as shown in Fig. 7(a). It was observed that the failure envelopes with respect to net normal stress revealed an approximately linear behaviour for all soil water content, and that the slope of the linear relationship increased as the matric suction increased, indicating that the effective friction angle increased with the increasing matric suction, as shown in Fig. 7(b). Fig. 7(c) shows the relationship between soil cohesion and matric suction. It could be seen that the cohesion had a remarkable improvement as the matric suction increased, proving that matric suction contributed to cohesion and shear strength significantly. The results indicated that when saturated, the 
cohesion value was close to $1 \mathrm{kPa}$ and the internal friction angle dropped to $15^{\circ}$. The strength of the undisturbed laterite specimen was affected by the amount of clay minerals. Ferric oxide and aluminum oxide in the clay wrapped around the clay clay particles to form peds, which in turn increased the shear strength. However, laterite soil will soften and disintegrate when exposed to water, and the strength will decrease [24]. The test results were reasonable.

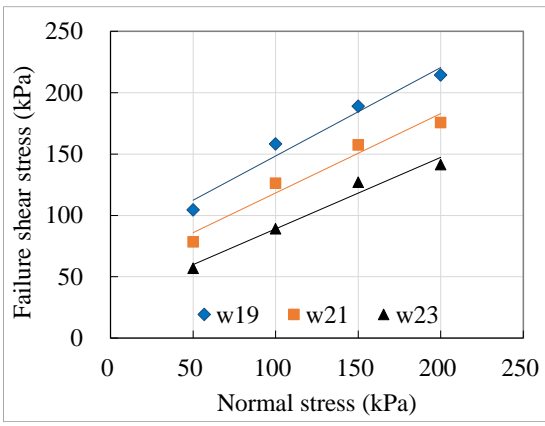

(a)

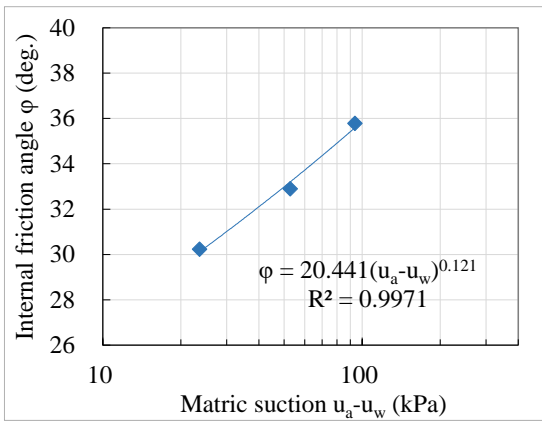

(b)

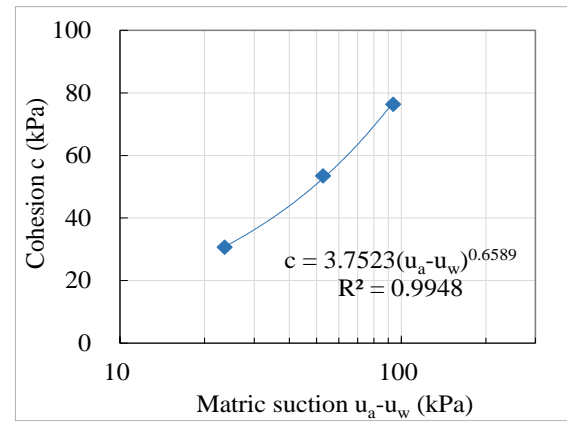

(c)

Fig. 7: (a) Failure envelope with respect to different soil water content. (b) Relationship between soil friction angle and matric suction. (c) Contribution of matric suction to cohesion.

\section{Conclusion}

This paper mainly presented experimental test results and an interpretation of the infiltration effect and shear strength behaviour of laterite terrace soil. In-situ and laboratory soil column infiltration observations were carried out. Meanwhile, direct shear tests under different soil water content conditions were implemented using a traditional direct shear apparatus. The following conclusions were drawn based on the laboratory study:

1. In a natural environmental, surface soil is affected by rainfall infiltration and the matric suction changes quickly. Even when the rainfall was only $1.5 \mathrm{~mm}$, the matric suction at $15 \mathrm{~cm}$ dropped quickly.

2. When the in-situ accumulated rainfall exceeded $40 \mathrm{~mm}$, rainwater could infiltrate more than $120 \mathrm{~cm}$; however, the matric suction at a depth of $120 \mathrm{~cm}$ showed a delay of one day.

3. After the laboratory soil column infiltration cycling test, a number of fine cracks were observed. On the laterite terraces, under the action of dry and wet circulation, fissure depth and openings increased, and the weathering speed and depth of the surface soil was accelerated.

4. The direct shear test results showed that the water content of the clayey soil increased greatly, its strength decreased greatly, and the soil matric suction decreased as the soil moisture content increased. The matric suction had a significant influence on the shear strength of the terrace soils.

5. The results of the direct shear test indicated that when soil was saturated due to rainfall infiltration, the cohesion and internal friction angle dropped to extremely low values of $1 \mathrm{kPa}$ and $15^{\circ}$, respectively. Therefore, when designing shallow-buried geotechnical structures, the rainwater infiltration depth and its negative effects on soil strength should be considered.

\section{References}

[1] D. G. Fredlund, H. Rahardjo, "Soil mechanics for unsaturated soils," John Wiley \& Sons, Inc., New York, 1993.

[2] M. W. Gui, C. M. Yu, "Rate of strength increase of unsaturated soil," Canadian Geotechnical Journal, vol. 45, no. 9, pp. 1335-1343, 2008.

[3] M. J. Dumbleton, "Clay mineralogy of Borneo soils considered in relation to their origin and their properties as road making materials," in Proceedings of the $2^{\text {nd }}$ Asian Regional Conference on Soil Mechanics and Foundation Engineering, Tokyo, Japan, 1963, pp. 63-69.

[4] A. Ibrahim, M. Mukhlisin, O. Jaafar, "Rainfall Infiltration through Unsaturated Layered Soil Column," Sains Malaysiana, vol. 43, no. 10, pp. 1477-1484, 2014. 
[5] H. Yang, H. Rahardjo, E. C. Leong, "Behavior of Unsaturated Layered Soil Columns during Infiltration," Journal of Hydrologic Engineering, vol. 11, no. 4, pp. 329-337, 2006.

[6] A. G. Li, Z. Q. Yue, L. G. Tham, C. F. Lee, K. T. Law, "Field-monitored variations of soil moisture and matric suction in a saprolite slope," Canadian Geotechnical Journal, vol. 42, pp. 13-26, 2005.

[7] T. T. Lim, H. Rahardjo, M. F. Chang, and D. G. Fredlund, "Effect of rainfall on matric suction in a residual soil slope," Canadian Geotechnical Journal, vol. 33, pp. 618-628, 1996.

[8] C. Kristo, H. Rahardjo, A. Satyanaga, "Effect of variations in rainfall intensity on slope stability in Singapore," International soil and water conservation research, vol. 5, no. 4, pp. 258-264, 2017.

[9] D. I. Stannard, "Tensiometers - theory, construction, and use," Geotechnical Testing Journal, vol. 15, no. 1, pp. 48$58,1992$.

[10] J. Zhang, J. J. Jiao, J. Yang, "In situ rainfall infiltration studies at a hillside in Hubei Province," China Engineering Geology, vol. 57, no. 1, pp. 31-38, 2000.

[11] J. M. Gasmo, K. J. Hritzuk, H. Rahardjo, E. C. Leong, "Instrumentation of an unsaturated residual soil slope," Geotechnical Testing Journal, vol. 22, no. 2, pp. 128-137, 2000.

[12] L. T. Zhan, "Field and laboratory study of an unsaturated expansive soil associated with rain-induced slope instability," $\mathrm{PhD}$ thesis, Dept. of Civil \& Environmental Engineering, The Hong Kong University of Science and Technology.

[13] L. T. Zhan, W. W. Ng, D. G. Fredlund, "Field study of rainfall infiltration into a grassed unsaturated expansive soil slope," Canadian Geotechnical Journal, vol. 44, pp. 392-408, 2007.

[14] J. Ying, H. Liao, J. H. Yin, "An experimental study on the shear strength of undisturbed loess," In GeoShanghai International Conference, Shanghai, China, 2006.

[15] I. A. Ichola, L. Gaidi, "Study of the hydric behavior of double-layered columns of unsaturated soils - Analysis of water and suction profiles during infiltration tests," in $3^{\text {rd }}$ European Conference on Unsaturated Soils - E-UNSAT 2016, Paris, France, 2016, E3S, 9, 11014.

[16] C. Gallage, K. Tehrani, D. Williams, "Instrumented large soil-column to investigate climate-induced ground deformation in expansive Soil," in Proceedings of the 19th International Conference on Soil Mechanics and Geotechnical Engineering, Seoul, 2017, pp. 1147-1150.

[17] P. Sentenac, R. Lynch, M. Bolton, "Measurement of a side-wall boundary effect in soil columns using fibre-optics sensing," International Journal of Physical Modelling in Geotechnics, vol. 1, no. 4, pp. 35-41, 2001.

[18] S. H. Chung, C. C. Cheng, "Matric suction measurements of undisturbed clayey soil columns under the wetting and drying test," in The $8^{\text {th }}$ International Congress on Engineering and Information, Sapporo, Japan, 2018.

[19] S. K. Vanapalli, D. G. Fredlund, D. G. Pufahl, "The relationship between the soil-water characteristic curve and the unsaturated shear strength of a compacted glacial till," Geotechnical Testing Journal, vol. 19, pp. 259-268, 1996.

[20] T. A. Mohamed, F. H. Ali, S. Hashim, B. B. K. Huat, "Relationship between shear strength and soil water characteristic curve of an unsaturated granitic residual soil," American Journal of Environmental Sciences, vol. 2, no. 4, pp. 142$145,2006$.

[21] F. Q. Bai, S. H. Liu, "Measurement of the shear strength of an expansive soil by combining a filter paper method and direct shear tests," Geotechnical Testing Journal, vol. 35, no. 3, pp. 451-459, 2012.

[22] A. M. Elsharief, O. A. Abdelaziz, M. A. Dafallaa, "The influence of matric suction on the shear strength of highly plastic compacted swelling clays," Electronic Journal of Geotechnical Engineering, vol. 20, pp. 12555-12568, 2015.

[23] W. H. Zhou, X. Xu, "Shear strength of unsaturated completely decomposed granite soil under different stress state conditions," in The 15th Asian Regional Conference on Soil Mechanics and Geotechnical Engineering, Fukuoka, 2015.

[24] M. D. Gidigasu, "Laterite soil engineering," Elsevier Scientific Publishing Company, Amsterdam Oxford New York, 1976. 